\title{
Emission Characteristics of Pollutants from Co-processing Aged Refuse in a Bench-scale Simulated Cement Kiln
}

\author{
Tong Chen ${ }^{1}$, Yufeng Ma ${ }^{1}$, Mingxiu Zhan ${ }^{1,2^{*}}$, Xiaodong $\mathrm{Li}^{1}$, Jianhua Yan ${ }^{1}$ \\ ${ }^{I}$ State Key Laboratory of Clean Energy Utilization, Institute for Thermal Power Engineering, Zhejiang University, \\ Hangzhou 310027, China \\ ${ }^{2}$ College of Metrology and Measurement Engineering, China Jiliang University, Hangzhou 310018, China
}

\begin{abstract}
In this paper, a bench-scale simulated cement kiln was used to study the emission characteristics, as well as the main factors that influence them, of polychlorinated dibenzo- $p$-dioxins and dibenzofurans (PCDD/Fs), heavy metals, and hydrogen chloride $(\mathrm{HCl})$ in flue gas generated by co-processing combustible components of aged refuse (CCAR). The main combustible components were plastics, textiles, and woods, and the calorific value of CCAR $\left(>2.5 \times 10^{7} \mathrm{~J} \mathrm{~kg}^{-1}\right) \mathrm{was}$ much higher than that of original municipal solid waste (OMSW). De novo synthesis was the dominant PCDD/F formation pathway during the co-processing of CCAR, and CCAR with higher chlorine and $\mathrm{Cu}$ content tended to generate more PCDD/Fs. The concentration of the PCDD/Fs produced by the pure raw meal used in this experiment was $3.25 \mathrm{ng} \mathrm{m}^{-3}$ $\left(0.33 \mathrm{ng}\right.$ I-TEQ $\left.\mathrm{m}^{-3}\right)$, which increased to $3.87(0.56), 6.27(0.69)$, or $5.77 \mathrm{ng} \mathrm{m}^{-3}\left(0.72 \mathrm{ng}\right.$ I-TEQ $\left.{ }^{-3}\right)$ when CCAR from different landfill periods was mixed in, with the more chlorinated substituted PCDD/F congeners, especially 1,2,3,4,6,7,8HpCDF, exhibiting relatively high concentrations. However, the less chlorinated substituted PCDD/Fs, especially 2,3,7,8PCDD and 2,3,4,7,8-PeCDF, contributed the major share of the I-TEQ value. Feeding CCAR through the raw meal inlet increased the formation of PCDD/Fs. Principal component analysis (PCA) was conducted to identify the similarities and differences between congener distributions among the various samples. Overall, the co-processing of CCAR increases the concentration of pollutants and requires more effective technologies for controlling emissions.
\end{abstract}

Keywords: Simulated cement kiln device; Aged refuse; PCDD/Fs; Heavy metals; Emission characteristics; PCA.

\section{INTRODUCTION}

Aged refuse that is bio-stabilized through years in the landfill (Xie et al., 2012) can also be called "stabilized waste" or "mineralized waste." Substances such as kitchen waste, plants, and paper in the original municipal solid waste (OMSW) are basically decomposed into soil after long-term landfill, so the nature of the aged refuse is basically stable. Aged refuse can be divided into two categories according to the size of the particle: fine-grained $(<15 \mathrm{~mm})$ and coarse-grained $(>15 \mathrm{~mm})$. The main combustible components of coarse-grained aged refuse are substances that can be recycled and utilized, such as plastics, textiles, and woods (Zhao et al., 2001, 2002). Prechthai et al. (2008a) also found that coarse-grained aged refuse showed great potential for recycling as fuels and finegrained aged refuse as compost. According to statistics, the total aged refuse in the world reached 2 billion tons, of

\footnotetext{
${ }^{*}$ Corresponding author.

E-mail address: zhanmingxiu@cjlu.edu.cn
}

which at least 200 million tons of aged refuse exist in China (Zhao et al., 2007). Typically, aged refuse consists of about 20-40 wt.\% combustibles. This is often the case even when considering landfills located in completely different parts of the world (Prechthai et al., 2008b; Kaartinen et al., 2013; Krook et al., 2012). The capacity of the existing domestic landfills tends to be saturated, and the combustible components of aged refuse (CCAR) have a higher calorific value than the OMSW. Mining aged refuse from landfills and disposing of it properly can make room for landfilling more domestic waste. The key is how to achieve efficient and clean utilization of CCAR.

At present, researchers have already studied the disposal methods of aged refuse. In terms of fine-grained aged refuse, Hurst et al. (2005) believe it can be used as a covering material. Others found that fine-grained aged refuse can be used as an alternative low-cost treatment technology to physically adsorb pollutants from fishpond wastewater (Anijiofor et al., 2018). Liu et al. (2018) used fine-grained aged refuse as an efficient microbial agent, bio-stimulation agent, and soil conditioner. There is less research on coarse-grained aged refuse. Plasma gasification/ vitrification technology was used to convert combustible 
components into secondary fuels, but the energy consumption is too high to be used on a large scale. A mixture of waste plastic and waste lubricating oil with a mass ratio of $3: 2$ can be made into a fuel with a calorific value up to $2.9 \times$ $10^{7} \mathrm{~J} \mathrm{~kg}^{-1}$ by pyrolysis technology, but the viscosity may cause a malfunction of the incineration equipment (Wolfsberger et al., 2015). Esteban-Altabella et al. (2017) used a lysimeter to simulate how refuse from mechanicalbiological treatment (MBT) plants evolved in a landfill and believed refuse landfills could be a reservoir of future fuel. The potential uses of CCAR are follows: for sale as fuel or as refuse-derived fuel (RDF), pyrolysis oil, gasification heat treatment, granulation, regenerating various plastics and rubber appliances, etc. Cement kiln co-processing as a method for disposing of solid waste has been used widely, so it may be feasible to co-dispose of CCAR in a cement kiln.

According to the research results, cement kiln solid waste co-processing technology requires a long residence time and high combustion temperature. Flue gas disturbance is beneficial to the complete incineration and decomposition of waste. An alkaline environment can inhibit formation of polychlorinated dibenzo- $p$-dioxins and polychlorinated dibenzofurans (PCDD/Fs) (Wang et al., 2012; Liu et al., 2015). Bypass venting systems can reduce the chlorine source required for PCDD/F formation (Sutou et al., 1999; Membranes, 2008). The cement kiln firing system and the exhaust gas treatment system have high adsorption (Choy et al., 2004), sedimentation, and dust collection characteristics, and the PCDD/Fs can be solidified in the clinker without causing re-diffusion of PCDD/Fs (Baidya et al., 2016).

With regard to the co-processing of CCAR in cement kilns, the pollution profiles and mechanisms, especially PCDD/Fs, have not yet been studied, although many field investigations of flue gas emission levels and profiles of PCDD/Fs in cement kilns have been done (van Loo, 2007; Conesa et al., 2011; Li et al., 2015; Liu et al., 2015; Zhan et al., 2016a). It is important to study these issues to ensure sustainable development of CCAR co-processing in cement kilns.

In this work, CCAR was sampled from different landfill periods, and the composition and basic characteristics were analyzed. A bench-scale simulated cement kiln device was used to study the emission characteristics and main influencing factors of PCDD/Fs, heavy metals, and hydrogen chloride in flue gas from co-processed CCAR.

\section{MATERIALS AND METHODS}

\section{Aged Refuse Source}

The aged refuse was sampled at the landfill of Tianziling Waste Treatment Plant in Hangzhou, Zhejiang Province, China. The designed use period of this landfill was 13 years, and it holds more than 9 million tons of solid waste from Hangzhou and surrounding municipal areas. After screening of aged refuse, samples of fine-grained refuse (grains $<15 \mathrm{~mm}$ ) and samples of coarse-grained refuse (grains $>15 \mathrm{~mm}$ ) were obtained. We studied mainly the combustible components (plastics, textiles, and woods) in coarse-grained aged refuse. The landfill time is about 11 (S1), 15 (S2), or 19 years (S3). The fractions of the three combustible components are shown in Fig. 1.

The plastics in S1 are mainly plastic bags and beverage bottles, and the textiles are mainly chemical fiber clothing and cushion trim. S2 plastics are mainly plastic bags, film, and toys; the textiles are mainly chemical fiber clothing and cotton clothing. S3 plastics are mainly plastic bags and agricultural film and rubber; the textiles are mainly cotton clothes. The wood in all three samples is mainly branches or wood blocks; leaves are rarely found.

It can be clearly seen from Fig. 1 that plastics are not easily degraded, so they account for the largest proportions, $60.5,76.1$, and $84.9 \%$, and the proportion increases as the disposal time is extended. The proportion of textiles decreased sharply in older landfills, to $28.3,9.6$, and $5.5 \%$, and the proportion of wood was $11.2,14.3$, and $9.6 \%$, which was in the same range.

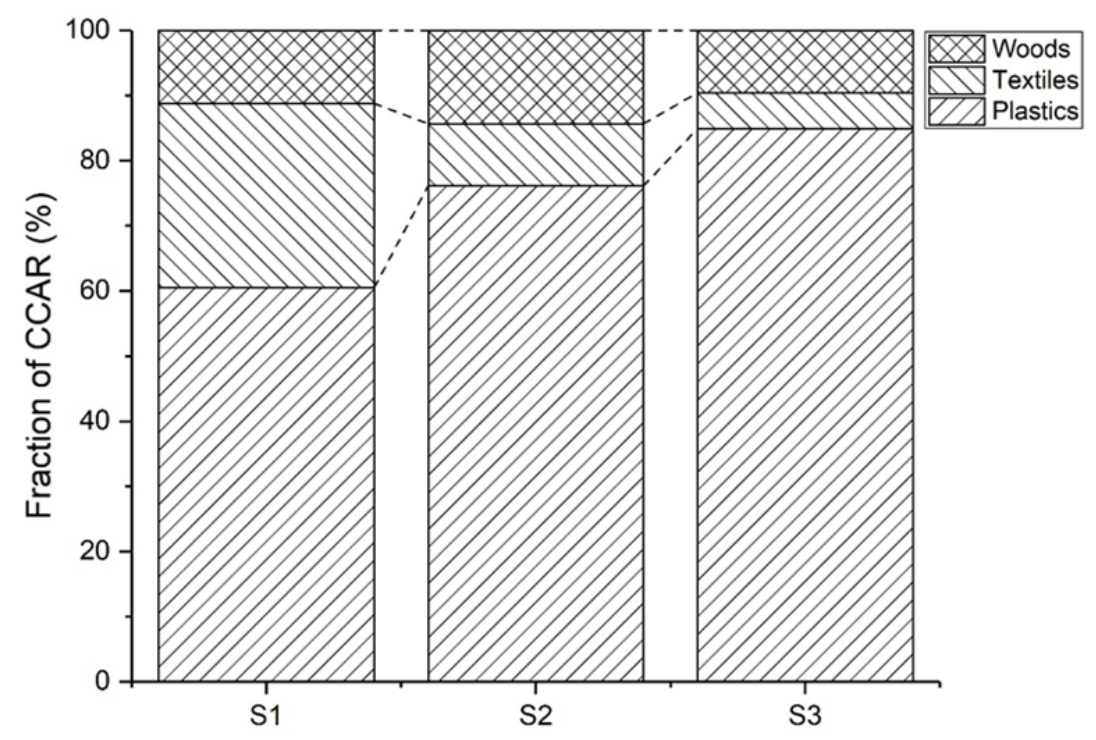

Fig. 1. Fraction of combustibles in the CCAR samples. 


\section{The Bench-scale Simulated Cement Kiln Device}

In the new dry-process cement production system, the cement clinker is produced in three main stages: (1) the high temperature incineration stage, (2) the precalciner burner and cyclone preheater stage $\left(850-250^{\circ} \mathrm{C}\right)$, and (3) the postpreheater stage (Karstensen, 2008). On the one hand, many scholars have verified that the second stage is the main area for pollutant formation (Phair, 2006; Pardo et al., 2011; Schneider et al., 2011; Van Thuong et al., 2014). On the other hand, the main components of CCAR are plastics, textiles, and woods; the content of heavy metals and chlorine are relatively high; and co-processing of CCAR may affect the normal operation of the cement kiln and increase $\mathrm{PCDD} / \mathrm{F}$ emissions. So, a bench-scale simulated cement kiln device (Fig. 2) was designed and manufactured to simulate the precalciner burner and cyclone preheater stages and to study the formation of pollutants, especially PCDD/Fs, in the flue gas. The overall height of the device is $\sim 1.8 \mathrm{~m}$, the height of the precalciner burner is $\sim 0.7 \mathrm{~m}$, and the total height of the 5-stage cyclone preheater is $0.7 \mathrm{~m}$. It is equipped with a temperature controller to control the temperature in the precalciner burner and keep it above $850^{\circ} \mathrm{C}$. There are two automatic screw feeders that can achieve continuous feed, which will be used to study the effects of adding CCAR from different locations on the formation of pollutants, especially PCDD/Fs. The device has a total of 6 sampling holes for collecting flue gas from each stage of the cyclone and the precalciner burners. A raw meal bucket and an ash bucket are used to collect raw meal and ash.

\section{Experimental Design}

The experimental conditions are presented in Table 1. The experiments for each group were carried out twice to ensure the accuracy and stability of the results. The temperature of the precalciner burner was controlled at $850^{\circ} \mathrm{C}$ and for the first stage of the cyclone separator $(\mathrm{C} 1)$ was $\sim 320^{\circ} \mathrm{C}$, as measured by a thermocouple during the experiment.

Experiments in Groups A, B, C, D, and E were conducted to learn the possible factors that influence pollutant formation from different CCAR and different adding positions. Experiments in Group A can be regarded as controls. Group B, C, and D be used to investigate the role of different CCAR in pollution formation. Groups $\mathrm{C}$ and $\mathrm{E}$ are conducted to determine the influence of adding CCAR in different positions (Automatic Feeder 1 and 2) on pollution formation.

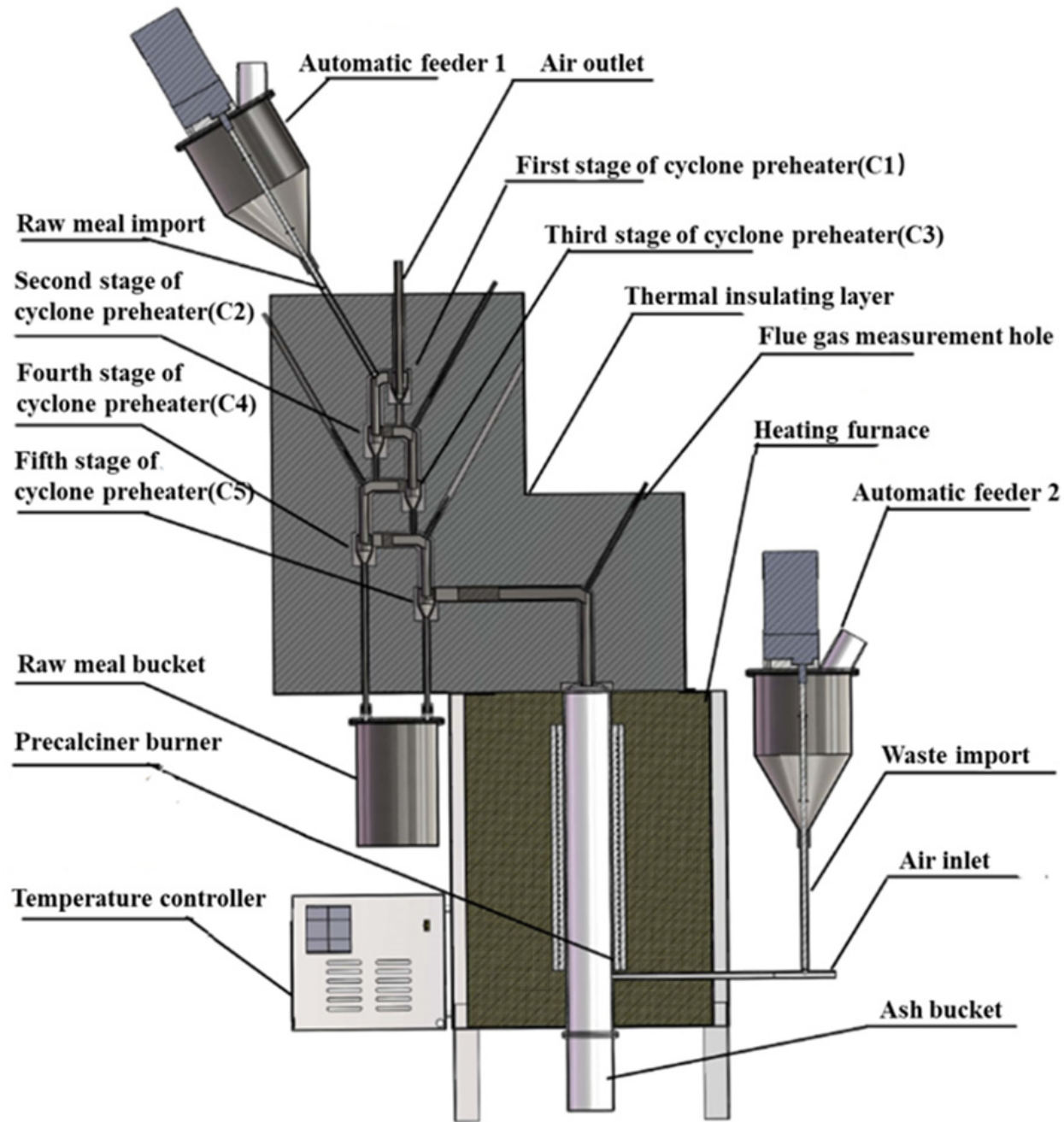

Fig. 2. Simulated cement kiln device. 
Table 1. Experimental conditions.

\begin{tabular}{llllll}
\hline Groups & Reactants & Automatic Feeders & Quantity $\left(\mathrm{g}(10 \mathrm{~min})^{-1}\right)$ & Flue gas $\left.(\mathrm{L} \mathrm{min})^{-1}\right)$ & Time $\left.^{(m i n}\right)$ \\
\hline A & Raw meal & 1 & 20 & 1 & 30 \\
B & 5\%S1 + Raw meal & 1 & 20 & 1 & 30 \\
C & 5\%S2 + Raw meal & 1 & 20 & 1 & 30 \\
D & 5\%S3 + Raw meal & 1 & 20 & 1 & 30 \\
E & Raw meal/S2 & $1 / 2$ & $19 / 1$ & 1 & 30 \\
\hline
\end{tabular}

Heavy metals in the flue gas were absorbed by a solution of $5 \%$ nitric acid and $10 \%$ hydrogen peroxide, and $\mathrm{HCl}$ was absorbed by a $0.1 \mathrm{~mol} \mathrm{~L}^{-1}$ sodium hydroxide solution. PCDD/Fs were collected by an XAD-II resin and toluene solution, and the toluene solution was placed in an ice bath. The device's total inlet flow rate was $20 \mathrm{~L} \mathrm{~min}^{-1}$.

\section{Analysis Procedures}

According to U.S. EPA Method 1613 (EPA, 1994) for purifying $\mathrm{PCDD} / \mathrm{F}$ samples, identification and quantification of PCDD/Fs were accomplished by high-resolution gas chromatography and high-resolution mass spectrometry (HRGC/HRMS) on a 6890 Series gas chromatograph (Agilent, USA) coupled with a JMS-800D mass spectrometer (JEOL, Japan). A DB-5ms capillary column (I.D.: $60 \mathrm{~m} \times 0.25 \mathrm{~mm}$; film thickness: $0.25 \mu \mathrm{m}$ ) was used to separate the $\mathrm{PCDD} / \mathrm{F}$ congeners. The mean recoveries of the standards for PCDD/Fs ranged from 30-135\%, which were within the acceptable range of $25-150 \%$. The toxic equivalencies (I-TEQs) were calculated using the NATO/CCMS factors.

\section{RESULTS AND DISCUSSION}

\section{Calorific Value, Proximate Analysis, and Ultimate Analysis of CCAR}

The samples were pulverized and subjected to calorific value measurement, proximate analysis, and ultimate analysis. The results are shown in Tables $2-3$. It can be seen that the plastics in the CCAR have a high calorific value, all above $3.0 \times 10^{7} \mathrm{~J} \mathrm{~kg}^{-1}$, and the calorific values of textiles and woods are lower, but also above $1.5 \times 10^{7} \mathrm{~J} \mathrm{~kg}^{-1}$. The total calorific values of $\mathrm{S} 1, \mathrm{~S} 2$, and $\mathrm{S} 3$ were calculated to be 2.7, 3.2, and $3.0 \times 10^{7} \mathrm{~J} \mathrm{~kg}^{-1}$, respectively; the total ash was $19.48,13.94$, and $17.17 \%$, respectively; and the total $\mathrm{V}_{\mathrm{ad}} \%$ ere $74.27,79.14$, and $75.67 \%$, respectively. Therefore, the value of thermal transformation of CCAR is high.

\section{Chlorine Content of CCAR}

The chlorine content of each CCAR and the OMSW is shown in Table 4. The plastics' chlorine content is the highest, the woods' chlorine content is the lowest, and the chlorine content increases as the disposal time is extended. The total chlorine content of S1, S2, and S3 was calculated to be $1.08,1.52$, and $4.12 \mathrm{wt.} \%$, respectively. Some researchers analyzed the chlorine content of municipal solid waste (MSW) in Shanghai during the period of 20072016, which ranged from 0.14 to 0.4 wt.\%, with an average of 0.27 wt. \% (Zhou et al., 2014). Others analyzed the chlorine content of MSW in Kaohsiung in 1998, 2005, and 2010, which was $0.42,0.37$, and 0.13 wt. $\%$, and the average value was 0.31 wt.\% (Huang et al., 2011). The chlorine content of CCAR was much higher than that of OMSW. This was similar to the findings by others (Rotheut and Quicker, 2017).

\section{CCAR Combustion and Volatile Matter Release \\ Characteristics}

CCAR was subjected to thermogravimetric experiments. The experimental results are shown in Figs. 3-5.

It can be seen in Figs. 3-5 that the ignition temperatures of the three samples are 365,395 , and $400^{\circ} \mathrm{C}$, which increases with the landfill age. The maximum combustion rates are $7.5,11.5$, and $7.7 \mathrm{wt} \% \mathrm{~min}^{-1}$, and the mean combustion rates are $1.28,1.44$, and $1.00 \mathrm{wt}^{2} \% \mathrm{~min}^{-1}$, which are similar to pulverized coal (1.00-1.40 $\left.\mathrm{wt}_{0} \% \mathrm{~min}^{-1}\right)$ and lower than biomass (1.5-1.6 wt.\% $\mathrm{min}^{-1}$ ) (Ávila et al., 2017; Mureddu et al., 2018). It can be seen that the longer landfill age corresponds to higher combustion rates. A different behavior has been observed for Sample 3 (S3). The reason may be the effect of ash content on combustion rate because different ash content can affect heat transfer (S3 contains more rubber than $\mathrm{S} 1$ and $\mathrm{S} 2$, which leaves much more residue after decomposing). Further analysis of the volatile release characteristics in combination with the

Table 2. Calorific value and proximate analysis of CCAR (Air-dried basis).

\begin{tabular}{lllllll}
\hline & No. & $\mathrm{M}_{\mathrm{ad}} \%$ & $\mathrm{~A}_{\mathrm{ad}} \%$ & $\mathrm{~V}_{\mathrm{ad}} \%$ & $\mathrm{Fc}_{\mathrm{ad}} \%$ & Calorific value $\left(\times 10^{6} \mathrm{~J} \mathrm{~kg}^{-1}\right)$ \\
\hline Plastics & 1 & 1.57 & 21.58 & 74.10 & 2.75 & 32.33 \\
& 2 & 1.32 & 14.18 & 81.76 & 2.74 & 35.55 \\
\multirow{5}{*}{ Textiles } & 3 & 1.22 & 16.52 & 78.18 & 4.08 & 32.18 \\
& 1 & 1.43 & 16.80 & 69.82 & 11.95 & 19.39 \\
& 2 & 2.22 & 18.35 & 74.21 & 5.22 & 28.18 \\
\multirow{2}{*}{ Woods } & 3 & 2.29 & 23.31 & 64.21 & 10.19 & 21.69 \\
& 1 & 5.89 & 14.92 & 67.72 & 11.47 & 17.11 \\
& 2 & 7.69 & 9.74 & 68.54 & 14.03 & 16.72 \\
& 3 & 6.01 & 19.39 & 60.01 & 14.59 & 15.54 \\
\hline
\end{tabular}


Table 3. Ultimate analysis of CCAR (Air-dried basis).

\begin{tabular}{lllllll}
\hline & No. & $\mathrm{C}_{\mathrm{ad}} \%$ & $\mathrm{H}_{\mathrm{ad}} \%$ & $\mathrm{~N}_{\mathrm{ad}} \%$ & $\mathrm{~S}_{\mathrm{t}, \mathrm{ad}} \%$ & $\mathrm{O}_{\mathrm{ad}} \%$ \\
\hline Plastics & 1 & 64.11 & 7.18 & 0.58 & 0.9 & 4.08 \\
& 2 & 70.71 & 7.89 & 0.5 & 0.64 & 4.76 \\
\multirow{5}{*}{ Textiles } & 3 & 52.4 & 5.76 & 0.44 & 0.71 & 22.95 \\
& 1 & 47.04 & 3.59 & 0.87 & 0.9 & 29.37 \\
\multirow{5}{*}{ Woods } & 2 & 62.3 & 6.45 & 3.8 & 0.86 & 6.02 \\
& 3 & 49.89 & 4.78 & 10.47 & 0.59 & 8.67 \\
& 1 & 41.28 & 3.38 & 0.62 & 0.29 & 33.62 \\
& 2 & 43.29 & 3.47 & 0.48 & 0.53 & 34.8 \\
\end{tabular}

Table 4. Chlorine contents of CCAR and OMSW (wt.\%).

\begin{tabular}{lllll}
\hline & Plastics & Textiles & Woods & Total chlorine contents \\
\hline S1 & 1.36 & 0.71 & 0.54 & 1.08 \\
S2 & 1.77 & 0.93 & 0.61 & 1.52 \\
S3 & 4.6 & 1.43 & 1.4 & 4.12 \\
Typical Chinese cities & $/$ & $/$ & $/$ & 0.64 \\
Kaohsiung & $/$ & $/$ & $/$ & 0.31 \\
\hline
\end{tabular}

(a)

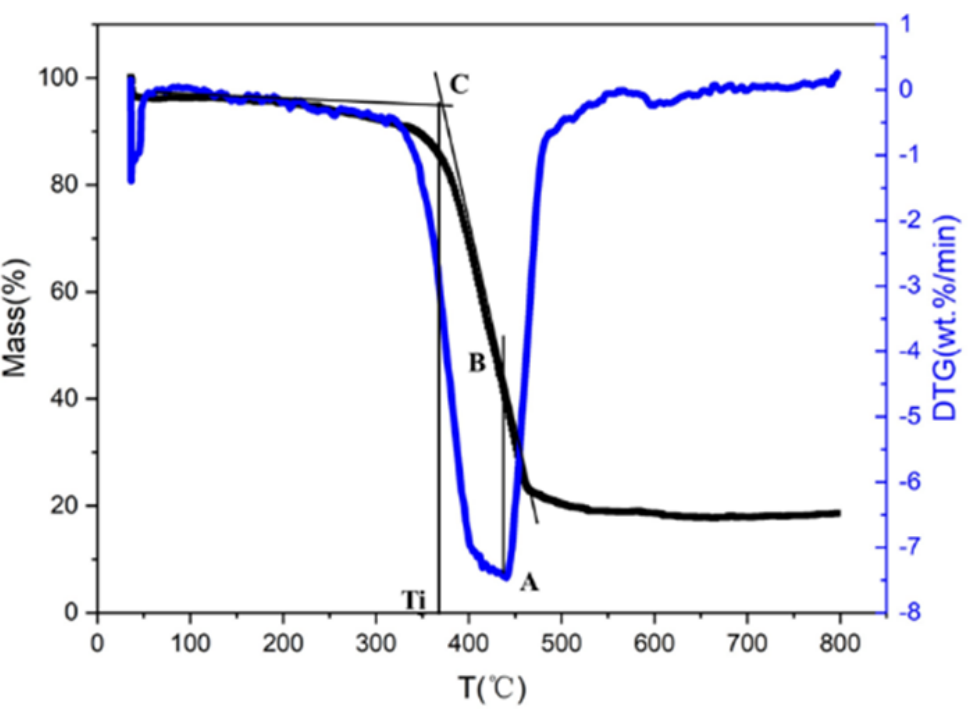

(b)

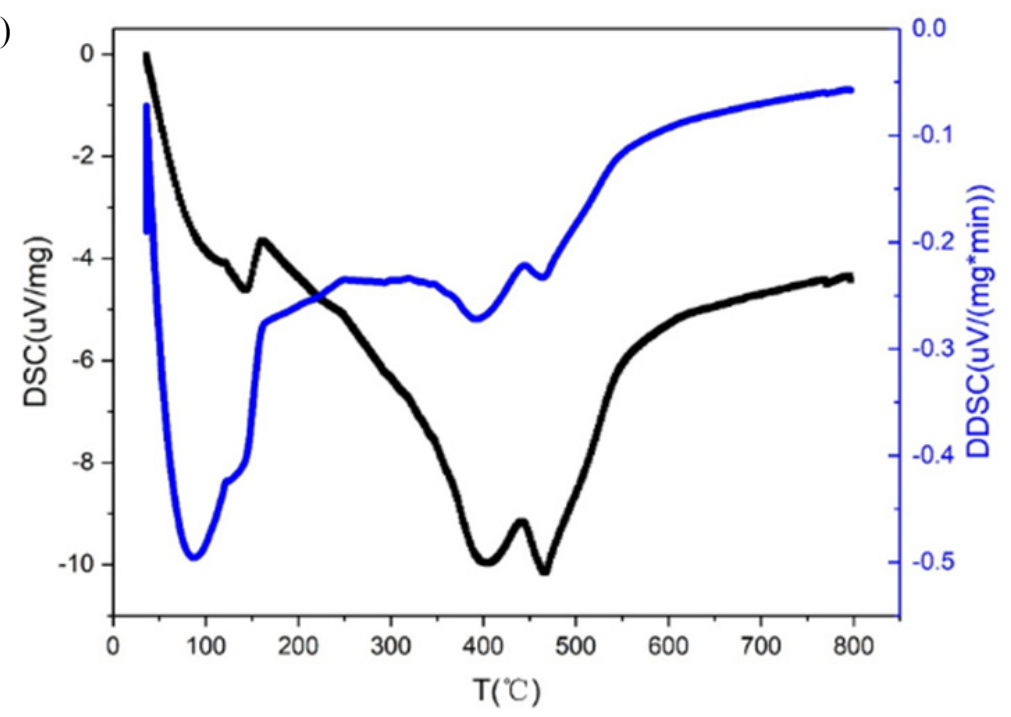

Fig. 3. CCAR S1 (a) TG/DTG curve and (b) DSC/DDSC curve. 
(a)

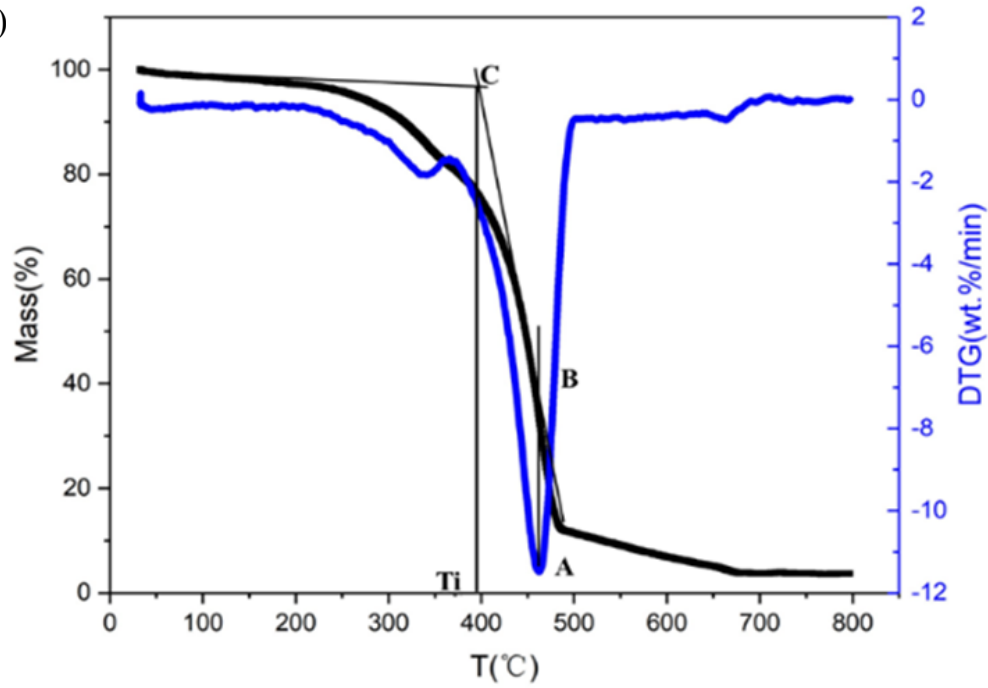

(b)

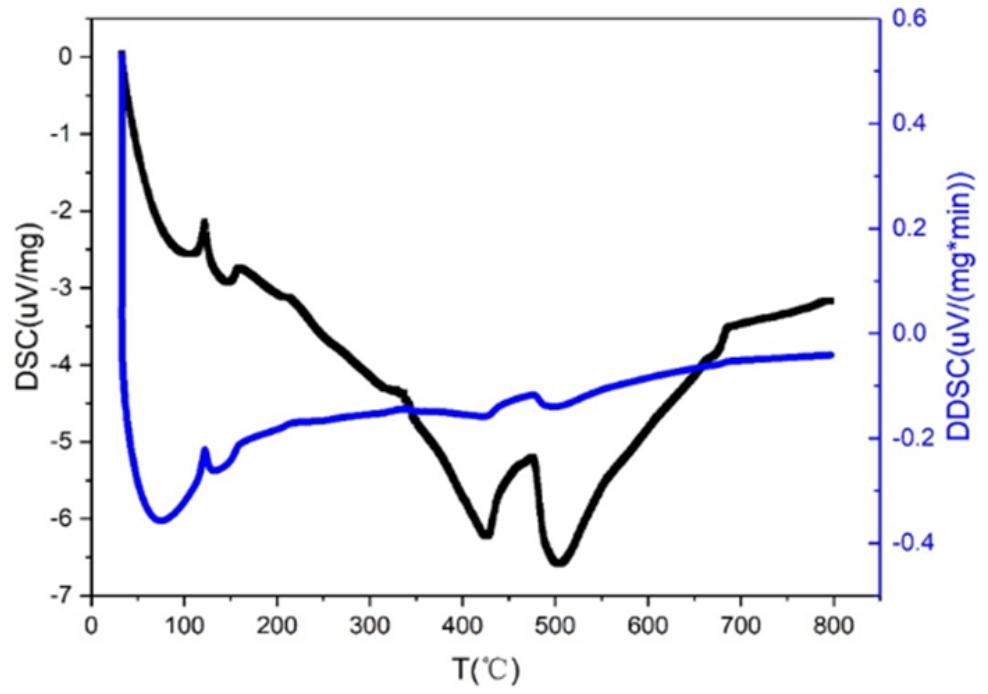

Fig. 4. CCAR S2 (a) TG/DTG curve and (b) DSC/DDSC curve.

DSC/DDSC curve shows that the three samples began to weigh less at $100-150^{\circ} \mathrm{C}$, corresponding to a small endothermic peak in the DCS curve, which may be the loss of free water; the maximum weight loss peak appeared at $\sim 500^{\circ} \mathrm{C}$. Two endothermic peaks and one exothermic peak appeared in the corresponding DCS curve. It can be inferred that in the nitrogen atmosphere, $\mathrm{HCl}, \mathrm{Cl}_{2}, \mathrm{H}_{2} \mathrm{~S}$, and $\mathrm{C}_{6} \mathrm{H}_{6}$ were mainly released at this temperature by further pyrolysis of macromolecular organic matter, which is inferred to be pyrolysis of plastics in CCAR. Between 650 and $700^{\circ} \mathrm{C}$, there is a small weight loss peak, mainly caused by the pyrolysis of coke. When the temperature was further increased to $800^{\circ} \mathrm{C}$, the thermogravimetric curves of samples were basically level, and the residue ratio was $<25 \%$.

\section{CCAR Heavy Metals}

The sorted plastics, textiles, and woods were pulverized separately and mixed according to the proportions, and then $0.1 \mathrm{~g}$ of each mixed sample (S1, S2, and S3) was subjected to microwave digestion to measure the heavy metal content; the results are shown in Table 5.
As shown in Table 5, the heavy metal content in CCAR is significantly higher than in OMSW. The OMSW 1 and 2 values are from other research (Jin et al., 2018) and also increase gradually with landfill age, which is similar to the results of another investigation (Zhao et al., 2007). The content is significantly higher than the Chinese national standard for heavy metals in the raw materials of the kiln (GB 30760-2014). According to the maximum allowable heavy metal content, it can be calculated that the amount of CCAR in the raw meal preparation system cannot exceed $15 \%$. Otherwise, the raw meal entering the kiln will not meet the kiln standard, and the pollutant emissions are likely to exceed the standard and may affect the quality of the cement. For example, when the amount of CCAR is $15 \%$, the cadmium and chromium content reaches $0.94(<1)$ and $97.4(<98) \mathrm{mg} \mathrm{kg}^{-1}$, respectively. The iron $(\mathrm{Fe})$ and copper $(\mathrm{Cu})$ content is $>1 \%$ and $>250 \mathrm{mg} \mathrm{kg}^{-1}$, respectively. During the thermal transformation process, certain forms of these heavy metals (mainly $\mathrm{CuCl}_{2}, \mathrm{FeCl}_{3}$, and other chlorine-containing metal compounds) have a strong influence on the formation of PCDD/Fs. 
(a)

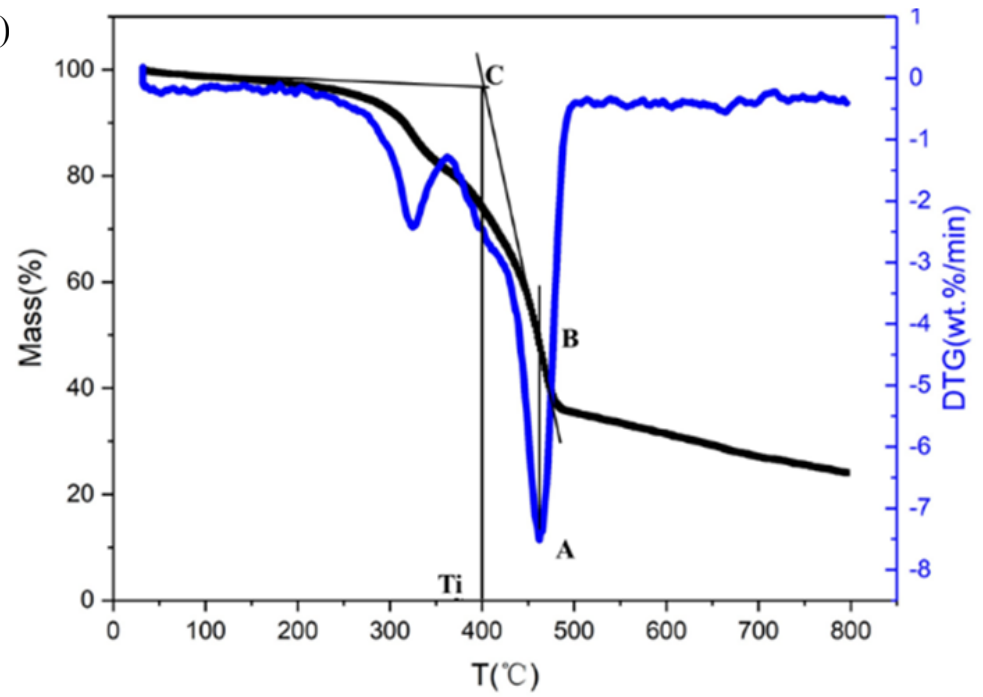

(b)

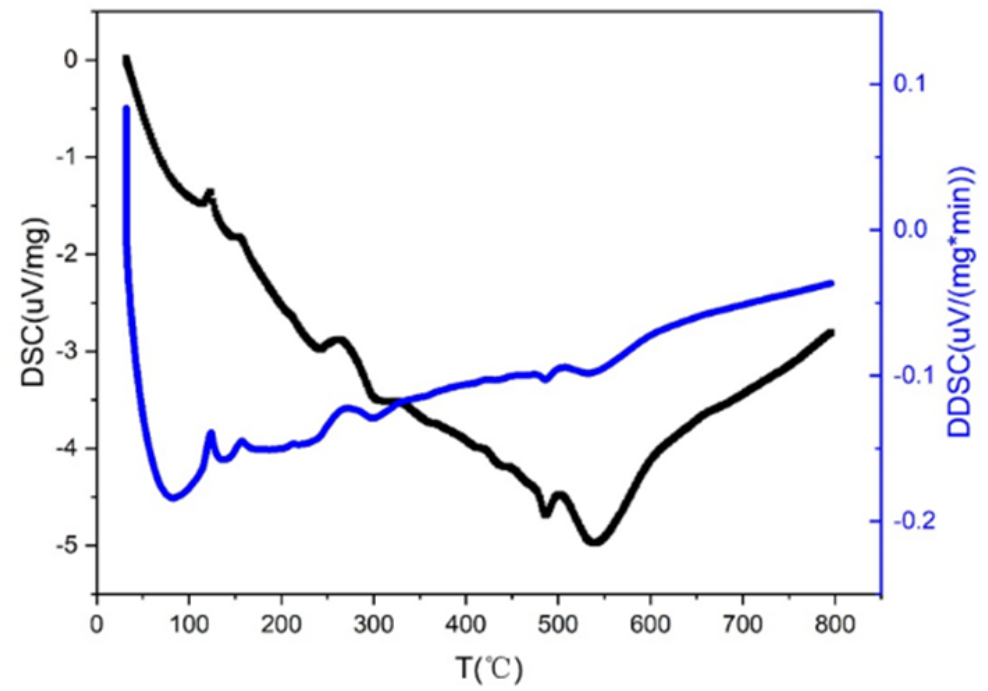

Fig. 5. CCAR S3 (a) TG/DTG curve and (b) DSC/DDSC curve.

Table 5. Heavy metal content of CCAR and OMSW ( $\left.\mathrm{mg} \mathrm{kg}^{-1}\right)$.

\begin{tabular}{|c|c|c|c|c|c|c|}
\hline & $\mathrm{S} 1$ & $\mathrm{~S} 2$ & S3 & OMSW 1 & OMSW 2 & Standard \\
\hline $\mathrm{Al}$ & $22,739.2$ & 21,746 & $25,983.9$ & 1 & / & / \\
\hline As & 51.4 & 49.5 & 53.4 & $0.05-43.7$ & $0.03-42.2$ & 28 \\
\hline $\mathrm{Cd}$ & 6.3 & 6.1 & 6.3 & $0.09-146.7$ & $1.86-169.2$ & 1 \\
\hline $\mathrm{Cr}$ & 638.2 & 613.3 & 649.1 & $6.8-302.5$ & $4.57-302.5$ & 98 \\
\hline $\mathrm{Cu}$ & 245.9 & 260.7 & 284 & $3.7-133.8$ & $6.05-145.9$ & 65 \\
\hline $\mathrm{Fe}$ & $13,860.3$ & 15,083 & $16,861.8$ & / & / & / \\
\hline $\mathrm{Pb}$ & 232.3 & 170.7 & 220.5 & $0.09-146.7$ & $1.9-169.2$ & 67 \\
\hline $\mathrm{Se}$ & 3.7 & 4.6 & 3.8 & / & / & / \\
\hline $\mathrm{Zn}$ & 612 & 686 & 671.8 & $3.86-274.5$ & $2.9-617.2$ & 361 \\
\hline
\end{tabular}

\section{The Analysis of Heavy Metals and HCl in C1 Flue Gas}

The results are shown in Table 6. It can be seen that the content of the volatile heavy metal $\mathrm{Hg}$ and the semivolatile heavy metals $\mathrm{As}, \mathrm{Pb}$, and $\mathrm{Cd}$ in $\mathrm{Cl}$ flue gas is low. Except for Group B, the two types of heavy metal concentrations before and after co-processing of CCAR are in the same range. The concentrations of low-volatility heavy metals, such as $\mathrm{Cr}, \mathrm{Cu}$, and $\mathrm{Sn}$, were high and increased (from $1.62 \mathrm{mg} \mathrm{m}^{-3}$ to $1.99,5.76$, and $6.42 \mathrm{mg} \mathrm{m}^{-3}$ for $\mathrm{B}, \mathrm{C}$, and $\mathrm{D}$, respectively) significantly after co-processing of CCAR because there are heavy metals, especially $\mathrm{Cr}$ and $\mathrm{Cu}$, in CCAR, which is consistent with the results reported by researchers who investigated cement kiln co-processing of waste tires (Conesa et al., 2016). In addition, most of the low-volatility heavy metals, such as $\mathrm{Cr}$ and $\mathrm{Cu}$, will be solidified in the cement clinker, and the change in 
Table 6. Concentrations of heavy metals and $\mathrm{HCl}$ in $\mathrm{C} 1$ flue gas $\left(\mathrm{mg} \mathrm{m}^{-3}\right)$.

\begin{tabular}{lllll}
\hline & $\mathrm{As}+\mathrm{Pb}+\mathrm{Cd}$ & $\mathrm{Cr}+\mathrm{Cu}+\mathrm{Sn}+\mathrm{Mn}+\mathrm{Ni}+\mathrm{Be}$ & $\mathrm{Hg}$ & $\mathrm{HCl}$ \\
\hline $\mathrm{A}$ & 0.17 & 1.62 & 0.010 & 6.81 \\
$\mathrm{~B}$ & 0.38 & 1.99 & 0.040 & 11.31 \\
$\mathrm{C}$ & 0.15 & 5.76 & 0.009 & 11.10 \\
$\mathrm{D}$ & 0.17 & 6.42 & 0.016 & 12.58 \\
$\mathrm{E}$ & 0.19 & 3.21 & 0.007 & 7.36 \\
\hline
\end{tabular}

concentration of these heavy metals will affect the cement compressive strength (Krobthong et al., 2012). $\mathrm{HCl}$ is mainly derived from the combustion of PVC substances and inorganic chlorides present in CCAR. In the case of full combustion, the chlorine in the PVC can be completely converted into $\mathrm{HCl}$. The release of $\mathrm{HCl}$ is increased in the presence of moisture and sulfur, and $\sim 50-60 \%$ of $\mathrm{NaCl}$ is converted to $\mathrm{HCl}$ (Kanters et al., 1996). The reactions are shown in Eqs. (1) and (2).

$$
\begin{aligned}
& \mathrm{C}_{\mathrm{n}} \mathrm{H}_{\mathrm{m}} \mathrm{Cl}_{\mathrm{p}}+\mathrm{\rho O}_{2} \rightarrow \mathrm{XCO}_{2}+\mathrm{YCO} \uparrow+\mathrm{ZH}_{2} \mathrm{O} \uparrow+\mathrm{WHCl} \uparrow \\
& 2 \mathrm{NaCl}(\mathrm{g})+\mathrm{SO}_{2}(\mathrm{~g})+0.5 \mathrm{O}_{2}+\mathrm{H}_{2} \mathrm{O}(\mathrm{g}) \rightarrow \mathrm{NaSO}_{4}(\mathrm{~g})+ \\
& \mathrm{HCl}(\mathrm{g})
\end{aligned}
$$

Except for Group A and Group E, the emissions of $\mathrm{HCl}$ are higher than the limit of $10 \mathrm{mg} \mathrm{m}^{-3}$ specified in the Chinese national standard (GB 30485-2013). Because the main CCAR components are plastics, textiles, and woods, the content of $\mathrm{Cl}$ is high, and the flue gas at $\mathrm{Cl}$ has not passed through the air pollution control device. In addition, the existence of a large amount of $\mathrm{Cl}$ will cause much harm. First of all, the existence of $\mathrm{HCl}, \mathrm{O}_{2}$, and precursors at a certain temperature $\left(250-600^{\circ} \mathrm{C}\right)$ will lead to synthesis of PCDD/Fs (Karstensen, 2008). Second, chloride, sulfate, and their compounds are responsible for the formation of low-temperature melts and crusts, which can cause different degrees of blockage in the kiln (Long et al., 2005). Finally, the excessive presence of $\mathrm{Cl}$ in cement will cause freezing and thawing of concrete and the corrosion of steel bars in concrete, affecting the service life and safety of concrete buildings (Wang et al., 2019).

\section{The Formation Characteristics of PCDD/Fs in C1 Flue Gas}

The Concentrations of PCDD/Fs

The PCDD/F formation increased as CCAR was added (results are shown in Table 7). The concentrations of PCDD/Fs were higher for Groups B, C, and D (5.82, 7.91, and $7.44 \mathrm{ng} \mathrm{m}^{-3}$, respectively) than for Group $\mathrm{A}\left(5.16 \mathrm{ng} \mathrm{m}^{-3}\right)$, and the corresponding TEQ values were also higher $(0.56$, 0.69 , and $0.72 \mathrm{ng}$ I-TEQ $\mathrm{m}^{-3}$, respectively) than for Group A $\left(0.33 \mathrm{ng}\right.$ I-TEQ $\left.\mathrm{m}^{-3}\right)$. The results show that the co-processing of CCAR does promote the formation of PCDD/Fs, which is consistent with the results reported by other research (Zhan et al., 2016b). The toxic equivalencies are much higher than the national limits $\left(<0.1 \mathrm{ng}\right.$ I-TEQ $\left.\mathrm{m}^{-3}\right)$ because no air pollution control system was used in this simulated device. However, after installing a new air pollution control system in a municipal solid waste incinerator (MSWI) in
Spain, the stack gas emissions of $\mathrm{PCDD} / \mathrm{Fs}$ fell from $3.26 \mathrm{ng}^{\mathrm{I}-T E Q ~ \mathrm{~m}^{-3}}$ to $<0.01 \mathrm{ng}$ I-TEQ $\mathrm{m}^{-3}$ (Abad et al., 2002). Meanwhile, the Cl-PCDD/Fs decreased slightly, indicating that the chlorination of PCDDFs was inhibited and less chlorinated PCDD/Fs are synthesized; this is maintained at around 6.5 basically.

In terms of raw meal, the ratio of PCDFs/PCDDs is 1.7, indicating that de novo synthesis was the dominant PCDD/F formation pathway for the cement kiln (Zhan et al., 2016a). The ratio of PCDFs/PCDDs increased from 1.7 (Group A) to 1.98 (Group B), 3.83 (Group C), and 3.45 (Group D) after co-processing of CCAR, indicating that co-processing of CCAR in a cement kiln further promotes the de novo synthesis of PCDD/Fs. It is well known that $\mathrm{CuCl}_{2}$ is an important metal catalyst for de novo synthesis (Huang and Buekens, 1995; Mubeen et al., 2017; Lin et al., 2018). S1 (11 years), S2 (15 years), and S3 (19 years) have different compositions of combustible components due to different landfill ages, and the heavy metal concentration (especially $\mathrm{Cu}$ and $\mathrm{Fe}$ ) and chlorine content are also different, which is the main reason for the difference in PCDD/Fs produced in Group B, Group C, and Group D. The overall trend is that CCAR with more chlorine and $\mathrm{Cu}$ is likely to generate more PCDD/Fs when co-processing.

Comparing the data of Groups $\mathrm{C}$ and $\mathrm{E}$, it can be seen that CCAR has different impacts on the formation of PCDD/Fs when input from different feed inlets. The addition of CCAR at the raw meal preparation system produces more $\mathrm{PCDD} / \mathrm{Fs}$ than addition at the precalciner burner. The $\mathrm{PCDD} / \mathrm{F}$ concentrations when the CCAR is input from the raw meal preparation system and the precalciner burner are 7.91 and $7.41 \mathrm{ng} \mathrm{m}^{-3}$, respectively, with corresponding TEQ values of 0.69 and $0.55 \mathrm{ng}$ I-TEQ $\mathrm{m}^{-3}$, respectively. The reason may be that the temperature at the precalciner burner is $850-900^{\circ} \mathrm{C}$, so the CCAR is more likely to be burned completely and fewer PCDD/Fs are formed. It is also confirmed that the main formation area of PCDD/Fs in the cement kiln is the cyclone preheater at the temperature range $250-500^{\circ} \mathrm{C}$, which verifies previous work of other researchers who believe that this area is the major area for PCDD/F formation (Xhrouet et al., 2001; Liu et al., 2015; Li et al., 2016).

\section{Congener Distributions of $P C D D / F S$}

The congener profile of PCDD/Fs helps determine their sources and helps us speculate about their potential formation mechanisms (Zhao et al., 2017). The congener profiles of the seventeen toxic 2,3,7,8-substituted PCDD/Fs in Groups A-E are shown in Fig. 6. Groups A and E mainly consisted of highly chlorinated congeners, and OCDD and 
Table 7. Concentration and distribution of seventeen 2,3,7,8-substituted PCDD/Fs in groups.

\begin{tabular}{lllllll}
\hline & $\mathrm{A}$ & $\mathrm{B}$ & $\mathrm{C}$ & $\mathrm{D}$ & $\mathrm{E}$ & Unit \\
\hline PCDDs & 1.91 & 1.95 & 1.64 & 1.67 & 3.59 & $\mathrm{ng} \mathrm{m}^{-3}$ \\
PCDFs & 3.25 & 3.87 & 6.27 & 5.77 & 3.82 & $\mathrm{ng} \mathrm{m}^{-3}$ \\
PCDD/Fs & 5.16 & 5.82 & 7.91 & 7.44 & 7.41 & $\mathrm{ng} \mathrm{m}^{-3}$ \\
PCDF/PCDD & 1.70 & 1.98 & 3.83 & 3.45 & 1.07 & $/$ \\
Cl-PCDD & 7.39 & 6.72 & 6.34 & 6.47 & 7.53 & $/$ \\
Cl-PCDF & 6.71 & 6.34 & 6.43 & 6.41 & 6.38 & $/$ \\
Cl-PCDD/Fs & 6.97 & 6.47 & 6.41 & 6.42 & 6.94 & $/$ \\
I-TEQ & 0.33 & 0.56 & 0.69 & 0.72 & 0.55 & ng I-TEQ m $^{-3}$ \\
\hline
\end{tabular}

(a)

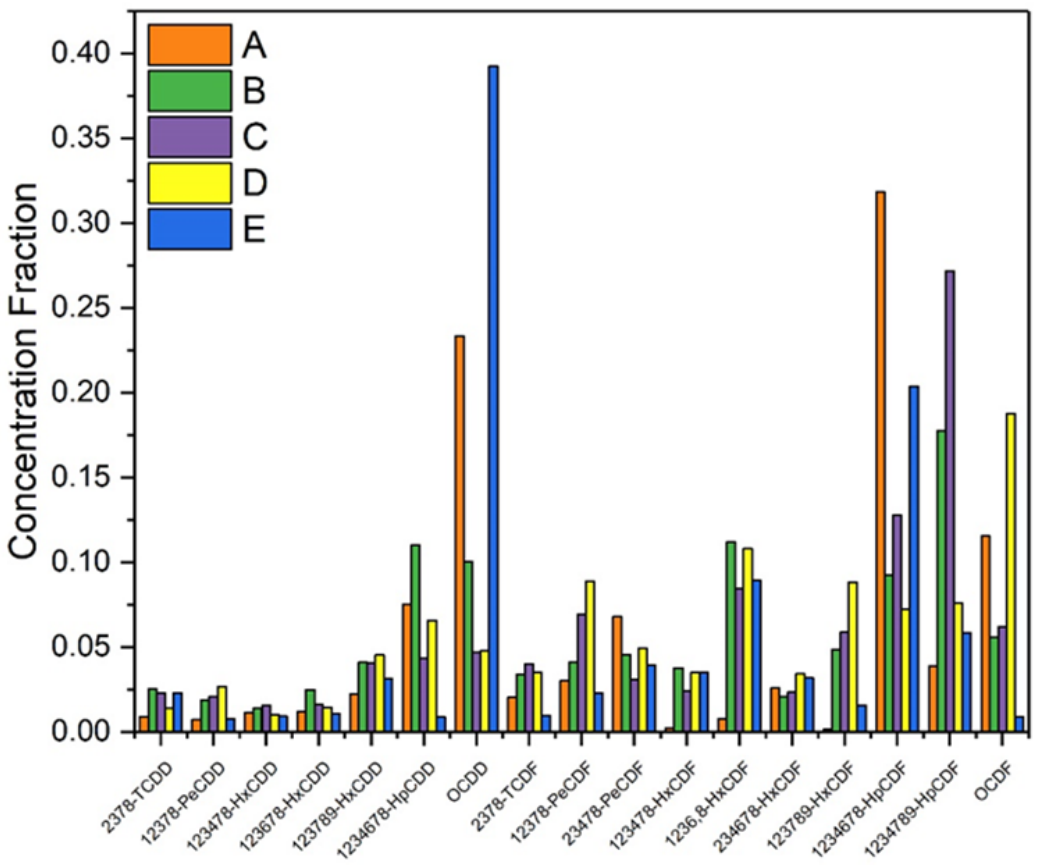

(b)

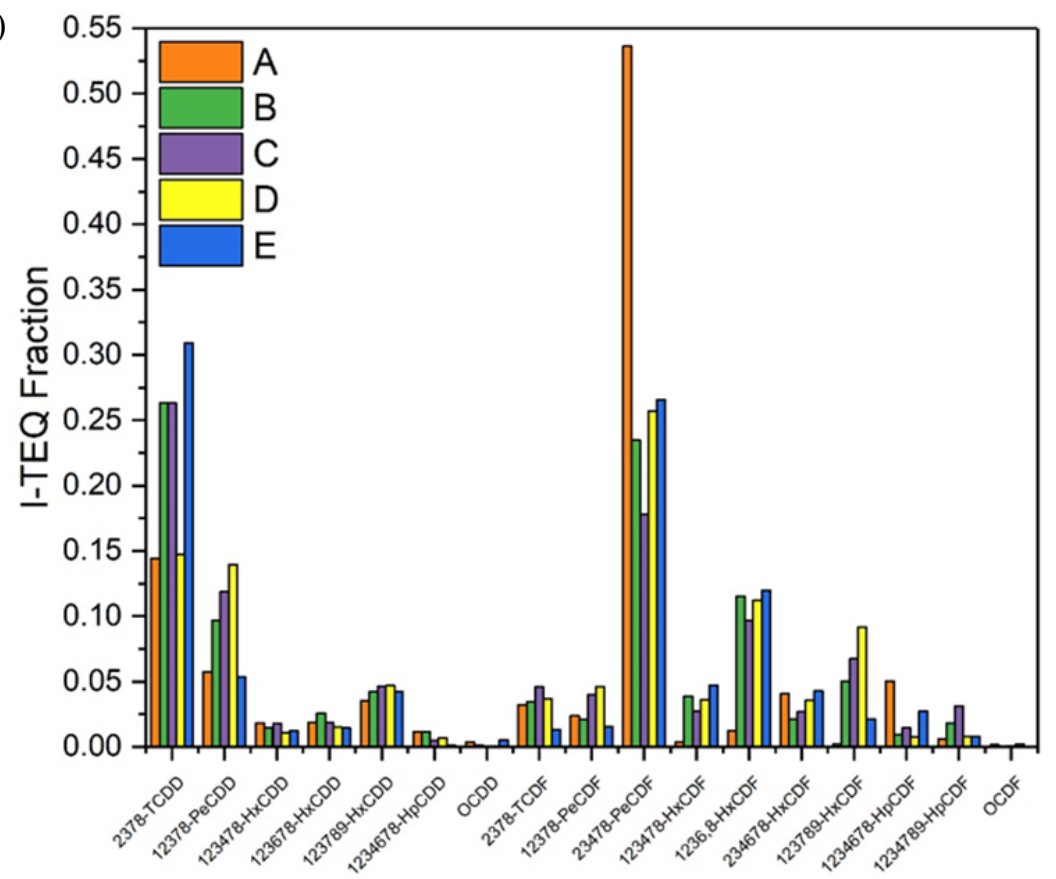

Fig. 6. Congener distribution of seventeen 2,3,7,8-substituted PCDD/Fs in Groups A-E: (a) PCDD/F concentration distribution and (b) PCDD/F TEQ values distribution. 
$1,2,3,4,6,7,8-\mathrm{HpCDF}$ were the leading congeners, with the fractions of 55.1 and $59.5 \%$, respectively. Similar results were also found in previous studies on the emission concentrations and emission factors of PCDD/Fs from cement kilns in China (Zou et al., 2018). The distribution of other congeners was uniform. This indicates that the addition of CCAR at the precalciner burner has little effect on the distribution of PCDD/F congeners. In Group B, 1,2,3,4,6,7,8-HpCDD, OCDD, 1,2,3,6,7,8-HxCDF, $1,2,3,4,6,7,8-\mathrm{HpCDF}$, and $1,2,3,4,7,8,9-\mathrm{HpCDF}$ were the five most abundant congeners, with the total fraction of $59.3 \%$. The main PCDD/Fs produced in Groups C and D were PCDFs. Group $\mathrm{C}$ was dominated by two highly chlorinated PCDF isomers, 1,2,3,4,6,7,8-HpCDF and $1,2,3,4,7,8,9-\mathrm{HpCDF}$, and the sum of the two was $39.8 \%$. The distribution of other PCDF isomers was uniform. The fraction of OCDF in Group D reached 18.8\%, and the distribution of other PCDF congeners was uniform.

The major contributions to the total TEQ were usually from 2,3,7,8-TCDD and 2,3,4,7,8-PeCDF, accounting for 68.0, 49.7, 44.3, 40.3, and 57.5\% for Groups A, B, C, D, and $\mathrm{E}$ respectively, which was similar to the findings by others (Abad et al., 2004; Rivera-Austrui et al., 2014), but this is different from the distribution of PCDD/F TEQ values in the flue gas (the 2,3,7,8-PCDF toxic equivalency contribution is the largest, accounting for $60-68 \%$ ) when Conesa et al. (2016) studied cement kiln co-processing of solid recovered fuel (SRF) and waste tires. This may be due to the different physical and chemical characteristics, dosage, and feeding position of the waste. And this is also different from the distribution of PCDD/F TEQ values in the flue gas when other researchers studied the emissions factors of PCDD/Fs from the stack flue gas of an MSWI (Hsieh et al., 2018; Zhan et al., 2018). This may be due to the different characteristics between CCAR and OMSW.
The CCAR of B, C, and D in this study was added in the raw meal preparation system, and the dosage was $5 \%$, while in another study, the waste as substitute fuel was added at the rotary kiln, and the replacement ratio was as high as $40 \%$ (Conesa et al., 2008).

\section{Principle Component Analysis}

Principal component analysis (PCA) was used to learn the similarities and differences of congener distributions among various samples (Fig. 7). The matrix is used to statistically investigate the signatures representing ten $\mathrm{PCDD} / \mathrm{F}$ homologue groups of all five samples. Before statistical analysis, no data transformation was performed. Factor 1 and Factor 2 separate all samples into two clusters (A and B), which separately explains 65.5 and $22.1 \%$ of the total variance. PCA shows that homologue profiles of Group E are closer to those of Group A, and homologue profiles of Groups B, C, and D are similar. In general, results of clustering obtained from PCA are in accordance with the former discussion. This further verified that the CCAR is completely burned in the precalciner burner, which has little effect on the distribution of congeners ( $\mathrm{E}$ is compared with A), but that is added at the raw meal preparation system would significantly influence the distribution of congeners (B, C, and D are compared with A).

\section{CONCLUSION}

The CCAR samples selected for co-processing in this study were sourced from 11-, 15-, and 19-year-old landfills and possessed calorific values as high as $2.7,3.2$, and $3.0 \times$ $10^{7} \mathrm{~J} \mathrm{~kg}^{-1}$, respectively. However, the samples also contained high amounts of chlorine ( $>1$ wt.\%) and heavy metals, especially $\mathrm{Cu}\left(>250 \mathrm{mg} \mathrm{kg}^{-1}\right)$; hence, the potential risks posed by co-processing CCAR must be carefully evaluated.

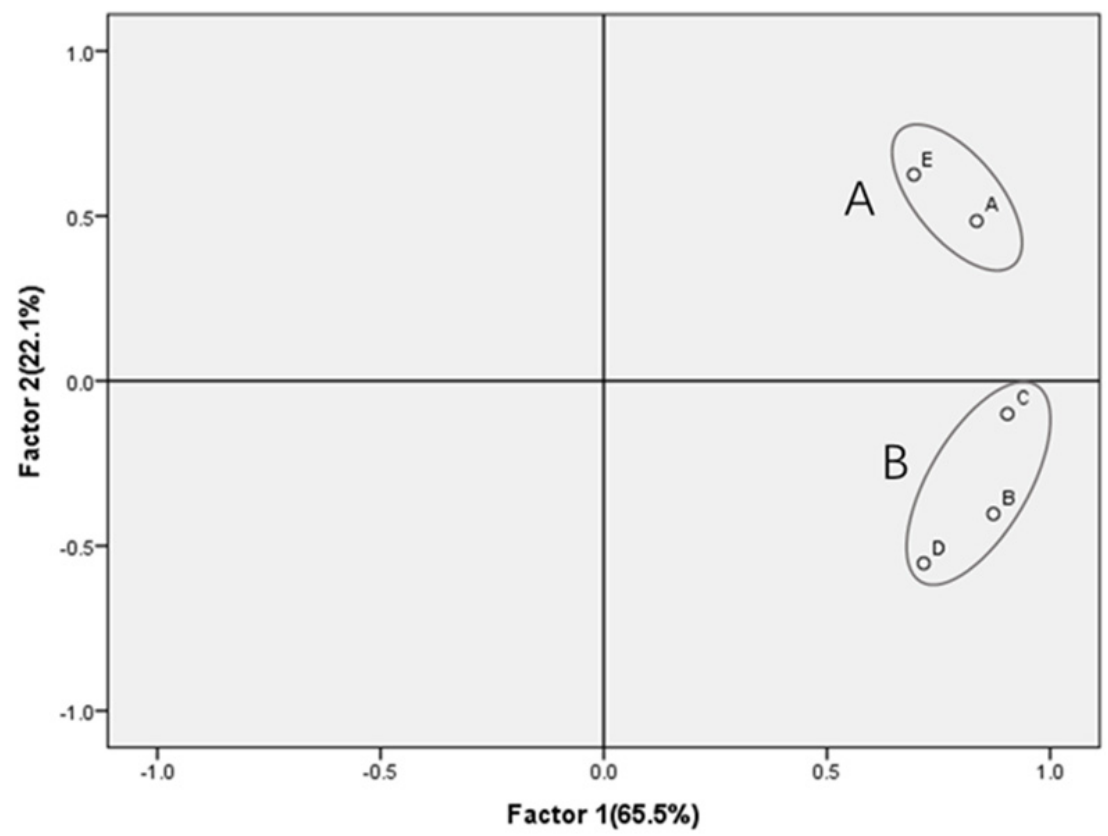

Fig. 7. Principle component analysis of homologue profiles. 
After the samples were co-processed using a simulated cement kiln, the concentrations of heavy metals in the flue gas rose, particularly for low-volatility heavy metals, such as $\mathrm{Cr}, \mathrm{Cu}$, and $\mathrm{Sn}$, which significantly increased (from 1.62 to $1.99,5.76$, and $6.42 \mathrm{mg} \mathrm{m}^{-3}$, respectively). PCDD/Fs are primarily produced via de novo synthesis, and co-processing further aggravated this process. The highly chlorinated congeners significantly contributed to the PCDD/F concentrations, whereas the less chlorinated congeners significantly contributed to the TEQ values. The amount of generated PCDD/Fs also increased with the landfill age. Furthermore, we determined that the PCDD/Fs mainly formed in the vicinity of the cyclone preheater, where the temperature range was $250-500^{\circ} \mathrm{C}$, thus verifying similar conclusions reached by other researchers for real-world cement manufacturing systems.

PCA also confirmed that the CCAR was fully combusted when input from the precalciner burner and therefore did not significantly affect the distribution of the PCDD/F congeners. By contrast, when the CCAR was fed from the raw meal inlet, the amount of generated PCDD/Fs increased; thus, the raw meal feeding system should not be used for CCAR.

\section{ACKNOWLEDGMENTS}

This study was supported by the Innovative Research Groups of the National Natural Science Foundation of China (No. 51621005), the National Natural Science Foundation of China (NSFC51806205).

\section{REFERENCES}

Abad, E., Adrados, M.A., Caixach, J. and Rivera, J. (2002). Dioxin abatement strategies and mass balance at a municipal waste management plant. Environ. Sci. Technol. 36: 92-99.

Abad, E., Martinez, K., Caixach, J. and Rivera, J. (2004). Polychlorinated dibenzo- $p$-dioxin/polychlorinated dibenzofuran releases into the atmosphere from the use of secondary fuels in cement kilns during clinker formation. Environ. Sci. Technol. 38: 4734-4738.

Anijiofor, S.C., Nik Daud, N.N., Idrus, S. and Che Man, H. (2018). Recycling of fishpond wastewater by adsorption of pollutants using aged refuse as an alternative low-cost adsorbent. Sustainable Environ. Res. 28: 315-321.

Ávila, I., Crnkovic, P.M., Luna, C.M.R., and Milioli, F.E. (2017). Use of a fluidized bed combustor and thermogravimetric analyzer for the study of coal ignition temperature. Appl. Therm. Eng. 114: 984-992.

Baidya, R., Ghosh, S.K. and Parlikar, U.V. (2016). Coprocessing of industrial waste in cement kiln - a robust system for material and energy recovery. In Selected Proceedings of the Tenth International Conference on Waste Management and Technology, Li, J. and Dong, F. (Eds.), pp. 309-317.

Choy, K.K.H., Ko, D.C.K., Cheung, W.H., Fung, J.S.C., Hui, D.C.W., Porter, J.F. and McKay, G. (2004). Municipal solid waste utilization for integrated cement processing with waste minimization: A pilot scale proposal. Process Saf. Environ. Prot. 82: 200-207.

Conesa, J.A., Gálvez, A., Mateos, F., Martín-Gullón, I. and Font, R. (2008). Organic and inorganic pollutants from cement kiln stack feeding alternative fuels. J. Hazard. Mater. 158: 585-592.

Conesa, J.A., Ortuño, N., Abad, E. and Rivera-Austrui, J. (2016). Emissions of PCDD/Fs, PBDD/Fs, dioxin likePCBs and PAHs from a cement plant using a long-term monitoring system. Sci. Total Environ. 571: 435-443.

Conesa, J.A., Rey, L., Egea, S. and Rey, M.D. (2011). Pollutant formation and emissions from cement kiln stack using a solid recovered fuel from municipal solid waste. Environ. Sci. Technol. 45: 5878-5884.

Esteban-Altabella, J., Colomer-Mendoza, F.J. and GallardoIzquierdo, A. (2017). Simulation of the behavior of a refuse landfill on a laboratory scale. J. Environ. Manage. 204: 144-151.

Hsieh, Y.K., Chen, W.S., Zhu, J.N. and Huang, Q.L. (2018). Characterization of polychlorinated dibenzo- $p$ dioxins and dibenzofurans of the flue gases, fly ash and bottom ash in a municipal solid waste incinerator. Aerosol Air Qual. Res. 18: 421-432.

Huang, H. and Buekens, A. (1995). On the mechanisms of dioxin formation in combustion processes. Chemosphere 31: 4099-4117.

Huang, S., Lee, R., and Lin, J.J. (2011). Characteristics of Composition and Temporal/Spatial Variation of Municipal Solid Waste in Kaohsiung City.

Hurst, C., Longhurst, P., Pollard, S., Smith, R., Jefferson, B. and Gronow, J. (2005). Assessment of municipal waste compost as a daily cover material for odour control at landfill sites. Environ. Pollu. 135: 171-177.

Jin, Q., Gao, H., Yue, B., Huang, Q.F., Wang, Y.T., Wu, X.H., Yu, J.Y. and Yang, H.Y. (2018). Heavy Metal Content of rural living solid waste and related source and distribution analysis. Huan Jing Ke Xue 39: 4385.

Kaartinen, T., Sormunen, K. and Rintala, J. (2013). Case study on sampling, processing and characterization of landfilled municipal solid waste in the view of landfill mining. J. Cleaner Prod. 55: 56-66.

Kanters, M.J., Van Nispen, R., Louw, R. and Mulder, P. (1996). Chlorine input and chlorophenol emission in the lab-scale combustion of municipal solid waste. Environ. Sci. Technol. 30: 2121-2126.

Karstensen, K.H. (2008). Formation, release and control of dioxins in cement kilns. Chemosphere 70: 543-560.

Krobthong, J., Rachakornkij, M. and Sricharoenchaikul, V. (2012). Distributions of $\mathrm{Cr}, \mathrm{Ni}, \mathrm{Cu}$ and $\mathrm{Zn}$ in hazardous waste co-processing in a pilot-scale rotary cement kiln. J. Appl. Sci. 12: 22-31.

Krook, J., Svensson, N. and Eklund, M. (2012). Landfill mining: A critical review of two decades of research. Waste Manage. 32: 513-520.

Li, Y.Q., Zhan, M.X., Chen, T., Zhang, J., Li, X.D., Yan, J.H. and Buekens, A. (2016). Formation, reduction and emission behaviors of CBzs and PCDD/Fs from cement plants. Aerosol Air Qual. Res. 16: 1942-1953.

Li, Y., Chen, T., Zhang, J., Meng, W., Yan, M., Wang, H. 
and $\mathrm{Li}, \mathrm{X}$. (2015). Mass balance of dioxins over a cement kiln in China. Waste Manage. 36: 130-135.

Lin, X.Q., Ji, L.J., Zhan, M.X., Wang, L.S., Chen, T., Lu, S.Y., Li, X.D. and Yan, J.H. (2018). Suppression of PCDD/Fs by raw meal in cement kilns. Aerosol Air Qual. Res. 18: 1032-1043.

Liu, G., Zhan, J., Zheng, M., Li, C., Li, L., Jiang, X., Wang, M., Zhao, Y. and Jin, R. (2015). Field pilot study on emissions, formations and distributions of PCDD/Fs from cement kiln co-processing fly ash from municipal solid waste incinerations. J. Hazard. Mater. 299: 471478.

Liu, Q., Li, Q., Wang, N., Liu, D., Zan, L., Chang, L., Gou, X. and Wang, P. (2018). Bioremediation of petroleumcontaminated soil using aged refuse from landfills. Waste Manage. 77: 576-585.

Long, S., Cheng, B., Huang, C. and Chen, Y. (2005). Cohesive properties of dust with melts of alkali, chlorine and sulphur in cement preheating decomposition system and effects of melts on buildups. J. Chin. Ceram. Soc. 33: 93-99.

Membranes, D. (2008). Reducing emissions: Filtering chloride emissions with a bypass cycle. Elsevier B.V, Oxford, pp. 36-37.

Mubeen, I., Lin, X.Q., Buekens, A., Cao, X., Lu, S.Y., Tang, M.H. and Yanl, J.H. (2017). PCDD/F formation in milled fly ash: Metal chloride catalysis. Aerosol Air Qual. Res. 17: 2858-2866.

Mureddu, M., Dessì, F., Orsini, A., Ferrara, F. and Pettinau, A. (2018). Air- and oxygen-blown characterization of coal and biomass by thermogravimetric analysis. Fuel 212: 626-637.

Pardo, N., Moya, J.A. and Mercier, A. (2011). Prospective on the energy efficiency and $\mathrm{CO}_{2}$ emissions in the EU cement industry. Energy 36: 3244-3254.

Phair, J.W. (2006). Green chemistry for sustainable cement production and use. Green Chem. 8: 763-780.

Prechthai, T., Padmasri, M. and Visvanathan, C. (2008a). Quality assessment of mined MSW from an open dumpsite for recycling potential. Resour. Conserv. Recycl. 53: 70-78.

Prechthai, T., Padmasri, M. and Visvanathan, C. (2008b). Quality assessment of mined MSW from an open dumpsite for recycling potential. Resour. Conserv. Recycl. 53: 70-78.

Rivera-Austrui, J., Martinez, K., Marco-Almagro, L., Abalos, M. and Abad, E. (2014). Long-term sampling of dioxin-like substances from a clinker kiln stack using alternative fuels. Sci. Total Environ. 485-486: 528-533.

Rotheut, M. and Quicker, P. (2017). Energetic utilisation of refuse derived fuels from landfill mining. Waste Manage. 62: 101-117.

Schneider, M., Romer, M., Tschudin, M. and Bolio, H. (2011). Sustainable cement production-present and future. Cem. Concr. Res. 41: 642-650.

Sutou, K., Harada, H. and Ueno, N. (1999). Chlorine bypass system for stable kiln operation and the recycling of waste. 1999 IEEE/-IAS/PCA Cement Industry Technical Conference. Conference Record (Cat. No.99CH36335), pp. 179-193.

Van Loo, W. (2007). Dioxin/furan formation and release in the cement industry. Environ. Toxicol. Pharmacol. 25: 128-130.

Van Thuong, N., Nam, V.D., Hue, N.T.M., Son, L.K., Van Thuy, N., Tung, H.D., Tuan, N.A., Minh, T.B., Huy, D.Q. and Minh, N.H. (2014). The emission of polychlorinated dibenzo- $p$-dioxins and polychlorinated dibenzofurans from steel and cement-kiln plants in Vietnam. Aerosol Air Qual. Res. 14: 1189-1198.

Wang, Y.F., Wang, L.C., Hsieh, L.T., Li, H.W., Jiang, H.C., Lin, Y.S. and Tsai, C.H. (2012). Effect of temperature and $\mathrm{CaO}$ addition on the removal of polychlorinated dibenzo-p-dioxins and dibenzofurans in fly ash from a medical waste incinerator. Aerosol Air Qual. Res. 12: 191-199.

Wang, Y., Zhu, H., Jiang, X., Lv, G. and Yan, J. (2019). Study on the evolution and transformation of $\mathrm{Cl}$ during co-incineration of a mixture of rectification residue and raw meal of a cement kiln. Waste Manage. 84: 112-118.

Wolfsberger, T., Nispel, J., Sarc, R., Aldrian, A., Hermann, R., Hoellen, D., Pomberger, R., Budischowsky, A. and Ragossnig, A. (2015). Landfill mining: Development of a theoretical method for a preliminary estimate of the raw material potential of landfill sites. Waste Manage. Res. 33: 671-680.

Xhrouet, C., Pirard, C. and De Pauw, E. (2001). De novo synthesis of polychlorinated dibenzo- $p$-dioxins and dibenzofurans on fly ash from a sintering process. Environ. Sci. Technol. 35: 1616-1623.

Xie, B., Xiong, S., Liang, S., Hu, C., Zhang, X. and Lu, J. (2012). Performance and bacterial compositions of aged refuse reactors treating mature landfill leachate. Bioresour. Technol. 103: 71-77.

Zhan, M.X., Fu, J.Y., Chen, T., Li, Y.Q., Li, X.D., Yan, J.H. and Buekens, A. (2016a). Adsorption of dioxins on the entering raw meal. Aerosol Air Qual. Res. 16: 17641774.

Zhan, M.X., Fu, J.Y., Havukainen, J., Chen, T., Li, X.D., Yan, J.H. and Buekens, A. (2016b). Recycling ash into the first stage of cyclone pre-heater of cement kiln. Waste Manage. 56: 229-237.

Zhan, M.X., Wang, T.J., Yang, J., Ji, L.J., Zhou, G.S., Chen, T., Li, X.D. and Lin, X.Q. (2018). The behaviors and relationships of $\mathrm{PCDD} / \mathrm{Fs}$ and chlorobenzenes in the whole process of one municipal solid waste incinerator. Aerosol Air Qual. Res. 18: 3134-3146.

Zhao, Y., Song, L., Huang, R., Song, L. and Li, X. (2007). Recycling of aged refuse from a closed landfill. Waste Manage. Res. 25: 130-138.

Zhao, Y., Zhan, J., Liu, G., Zheng, M., Jin, R., Yang, L., Hao, L., Wu, X., Zhang, X. and Wang, P. (2017). Evaluation of dioxins and dioxin-like compounds from a cement plant using carbide slag from chlor-alkali industry as the major raw material. J. Hazard. Mater. 330: 135141.

Zhao, Y.C., Chen, Z.G., Shi, Q.G. and Huang, R.H. (2001). Monitoring and long-term prediction of refuse compositions and settlement in large-scale landfill. Waste 
Manage. Res. 19: 160-168.

Zhao, Y.C., Wang, L.C., Hua, R.H., Xu, D.M. and Gu, G.W. (2002). A comparison of refuse attenuation in laboratory and field scale lysimeters. Waste Manage. 22: 29-35.

Zhou, H., Meng, A., Long, Y., Li, Q. and Zhang, Y. (2014). An overview of characteristics of municipal solid waste fuel in China: Physical, chemical composition and heating value. Renewable Sustainable Energy Rev. 36: 107-122.
Zou, L., Ni, Y., Gao, Y., Tang, F., Jin, J. and Chen, J. (2018). Spatial variation of PCDD/F and PCB emissions and their composition profiles in stack flue gas from the typical cement plants in China. Chemosphere 195: 491497.

Received for review, February 23, 2019

Revised, April 9, 2019 Accepted, May 13, 2019 